\title{
DETERMINATION OF PHENYLEPHRINE HYDROCHLORIDE IN PHARMACEUTICAL PREPARATIONS USING SPECTROPHOTOMETRIC METHOD
}

\author{
WASAN A AL-UZRI* \\ Department of Chemistry, College of Science, University of Baghdad, Jadriyah, Baghdad, Iraq. Email: wasanuzri67@yahoo.com
}

Received: 01 February 2019, Revised and Accepted: 09 April 2019

ABSTRACT

Objective: A simple and sensitive spectrophotometric method has been presented for the determination of phenylephrine hydrochloride by coupling reaction with diazotized sulfacetamide sodium.

Methods: The method is based on the diazotization reaction of sulfacetamide sodium with sodium nitrite in the presence of hydrochloric acid to form diazonium salt, which is coupled with the drug in alkaline medium to form azo dye, showing absorption maxima at $425 \mathrm{~nm}$.

Results: Calibration plot was linear over the concentration range of $2-24 \mu \mathrm{g} / \mathrm{mL}$ and detection limit of $0.278 \mu \mathrm{g} / \mathrm{mL}$ with a correlation coefficient of 0.9929. All different chemical and physical experimental parameters affecting on the development and stability of the colored product were carefully studied.

Conclusions: The proposed method was successfully applied to the determination of phenylephrine in nasal drops with good precision and sensitivity.

Keywords: Phenylephrine hydrochloride, Spectrophotometric determination, Sulfacetamide sodium, Diazotization and coupling.

(C) 2019 The Authors. Published by Innovare Academic Sciences Pvt Ltd. This is an open access article under the CC BY license (http://creativecommons. org/licenses/by/4. 0/) DOI: http://dx.doi.org/10.22159/ajpcr.2019.v12i5.32339

\section{INTRODUCTION}

Phenylephrine hydrochloride (PHP), [(R)-1-(3-hydroxyphenyl).2(methylamino) ethanol hydrochloride], is a white crystalline powder, freely soluble in water, melts at $143^{\circ} \mathrm{C}[1,2]$ and its chemical structure is:<smiles>CNC[C@H](O)c1cccc(O)c1</smiles>

It belongs to a group of drugs named sympathomimetics [3]. It stimulates alpha receptors in certain areas of the body. It is used locally, as decongestant, for non-specific and allergic conjunctivitis, sinusitis, and nasopharyngitis [4]. Phenylephrine nasal drops are used for treating symptoms such as runny nose, sneezing, itching of the nose, and throat [5]. PHP is normally used to increase the blood pressure in unstable patients with hypotension, especially resulting from septic shock [5]. Various methods reported in literature for analysis of phenylephrine hydrochloride. Examples of these methods are conductometric titration [6], voltammetry [7-9], thin-layer chromatography [10], high-performance liquid chromatography (HPLC) [11-14], flow injection [15-17], and fluorescence [18]. Among the different techniques, the most popular and simple method for rapid and trace analysis of drugs is spectrophotometry [19-26].

In this work, a spectrophotometric method for estimation of phenylephrine was described. The method was based on coupling reaction between diazotized sulfacetamide sodium with the medicine in alkaline medium to form a yellow water-soluble azo dye measured at $425 \mathrm{~nm}$. This method has been successfully applied for the determination of phenylephrine in nasal drops.

\section{METHODS}

\section{Apparatus}

An optima spectrophotometer ultraviolet-visible (Japan) double beam with $1 \mathrm{~cm}$ quartz cells was used in all absorbance measurements.

\section{Materials and reagents}

The reagent grade materials were used throughout this work. PHP, the working standard, was supplied by the State Company for Drug Industries and Medical Appliances (SDI), Samarra, Iraq. Pharmaceutical formulations (Nasophrine Nasal Drops [0.25\%], SDI, Samarra, Iraq, and Vibrocil Nasal Drops [2.5 mg], Novartis Consumer Health, SA, Switzerland) were obtained from local markets. Sulfacetamide sodium (SDI, Samarra, Iraq), sodium nitrite (Merck), hydrochloric acid $(\mathrm{HCl})$ $(\mathrm{BDH})$, and sodium hydroxide $(\mathrm{NaOH})(\mathrm{BDH})$ were used.

\section{Preparation of solutions}

PHP stock standard solution $(1000 \mu \mathrm{g} / \mathrm{mL})$ was prepared by dissolving $0.100 \mathrm{~g}$ of pure PHP in distilled water and made up to $100 \mathrm{~mL}$ volumetric flask with distilled water. Working standard solutions were prepared by suitable dilution of the stock standard solution with distilled water.

Sodium nitrite solution $\left(3.9 \times 10^{-3} \mathrm{M}\right)$ was prepared by dissolving $0.0673 \mathrm{~g}$ of sodium nitrite in distilled water and diluting to the mark in $250 \mathrm{~mL}$ volumetric flask.

$\mathrm{HCl}$ solution (0.5 M) was prepared by diluting $10.88 \mathrm{~mL}$ of $11.49 \mathrm{M}$ of concentrated $\mathrm{HCl}$ with distilled water in $250 \mathrm{~mL}$ volumetric flask.

Sulfacetamide sodium solution $(0.1 \%)$ was prepared by dissolving $0.1 \mathrm{~g}$ of sulfacetamide sodium in distilled water and diluting to $100 \mathrm{~mL}$ volumetric flask with the same solvent.

$\mathrm{NaOH}$ solution (2 M) was prepared by dissolving $20 \mathrm{~g}$ of $\mathrm{NaOH}$ with distilled water in $250 \mathrm{~mL}$ volumetric flask.

\section{General procedure for calibration}

About $2 \mathrm{~mL}$ of $0.1 \%$ sulfacetamide sodium was transferred into a series of $25 \mathrm{~mL}$ calibrated flask. To this solution, equimolar of sodium nitrite solution $\left(3.9 \times 10^{-3} \mathrm{M}\right)$ was added and the acidity was adjusted with $1 \mathrm{~mL}$ of $0.5 \mathrm{M} \mathrm{HCl}$ solution. The solution was shaken thoroughly. Then, an aliquot of a standard solution $(500 \mu \mathrm{g} / \mathrm{mL})$ containing $0.1-1.2 \mathrm{~mL}$ of PHP was 
transferred into this series of $25 \mathrm{~mL}$ calibrated flasks and $1 \mathrm{~mL}$ of $2 \mathrm{M}$ $\mathrm{NaOH}$ solution was added, and the contents were diluted to the mark with distilled water and mixed well. After $15 \mathrm{~min}$, the absorbance of the colored azo dye was measured at $425 \mathrm{~nm}$ against the corresponding reagent blank. For the optimization of conditions and in all subsequent experiments, $1 \mathrm{~mL}$ of $500 \mu \mathrm{g} / \mathrm{mL}$ of PHP in a final volume of $25 \mathrm{~mL}$ was used.

\section{Procedure for PHP in nasal drops}

The contents of three bottles of nasal drops were mixed. An aliquot corresponding to $50 \mathrm{mg}$ of PHP was diluted to $50 \mathrm{~mL}$ with distilled water in a volumetric flask to obtain $500 \mu \mathrm{g} / \mathrm{mL}$ of PHP. Further, appropriate solutions of pharmaceutical preparations were made by simple dilution with distilled water

\section{RESULTS AND DISCUSSION}

\section{Determination of absorption maximum}

An aqueous solution of PHP is reacted with diazotized sulfacetamide sodium in alkaline medium giving yellow dye which became stable after $15 \mathrm{~min}$ and has a maximum absorption at $425 \mathrm{~nm}$. Fig. 1 shows the spectra of the product formed.

\section{Optimization of the experimental conditions}

The effects of various parameters on the absorption intensity of the formed product were optimized.

\section{Effect of the volume of $\mathrm{HCl}(0.5 \mathrm{M})$}

The effect of different volumes $(0.3-3 \mathrm{~mL})$ of $\mathrm{HCl}$ was examined on the maximum absorbance of the formed product. Fig. 2 shows that $1 \mathrm{~mL}$ of $\mathrm{HCl}(0.5 \mathrm{M})$ was enough to obtain a maximum absorbance.

Effect of the volume of sulfacetamide sodium (0.1\%)

The effect of different volumes $(0.5-4 \mathrm{~mL})$ of sulfacetamide sodium was examined on the maximum absorbance of the formed azo dye. Fig. 3

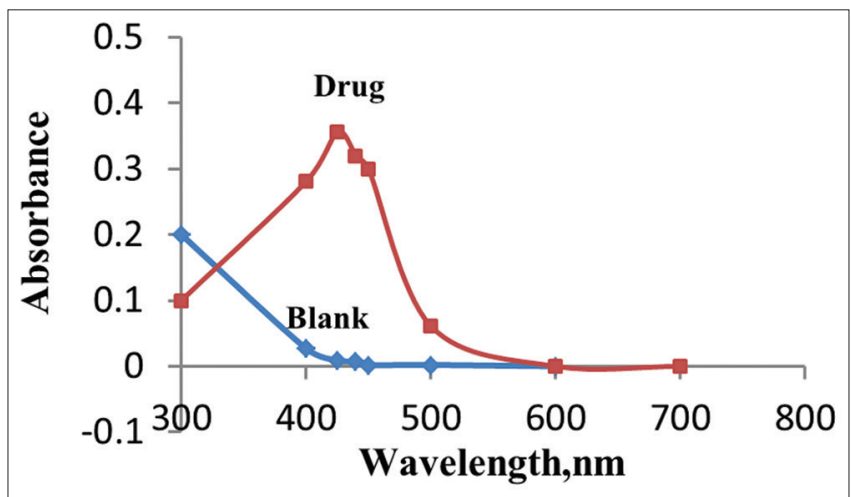

Fig. 1: Absorption spectra of the azo dye $(20 \mu \mathrm{g} / \mathrm{mL})$ of phenylephrine hydrochloride against reagent blank and blank against distilled water

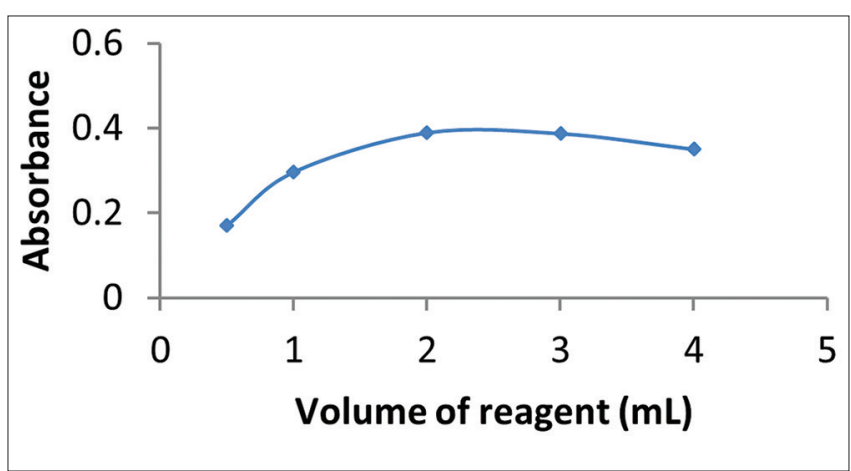

Fig. 2: Effect of the volume of hydrochloric acid ( $0.5 \mathrm{M})$ for the determination of phenylephrine hydrochloride $(20 \mu \mathrm{g} / \mathrm{mL})$ shows that $2 \mathrm{~mL}$ of sulfacetamide sodium $(0.1 \%)$ was enough to obtain a maximum absorbance.

\section{Effect of the volume of $\mathrm{NaOH}(2 \mathrm{M})$}

The effect of different volumes $(0.5-3 \mathrm{~mL})$ of $\mathrm{NaOH}$ was examined on the maximum absorbance of the formed product. Fig. 4 shows that $1 \mathrm{~mL}$ of $\mathrm{NaOH}(2 \mathrm{M}$ ) was enough to obtain a maximum absorbance.

Effect of reaction time

The stability of the product was studied for $180 \mathrm{~min}$ following the mixing of the reagents. The colored product developed rapidly after mixing and attained maximum absorbance about $15 \mathrm{~min}$ at room temperature. The color was stable for a period of $180 \mathrm{~min}$.

\section{Structures of the products}

The stoichiometry of the reaction between PHP and diazotized sulfacetamide sodium was investigated under the recommended optimum conditions using continuous variation method. The result obtained in Fig. 5 shows that a 1:2 azo dye was formed between PHP and diazotized sulfacetamide sodium.

A reaction subsequent based on the above result is shown in Scheme (1) [22]

Determination of stability constant and Gibbs free energy of the reaction

The apparent stability constant was calculated by comparing the absorbance of a solution containing $1 \mathrm{~mL}$ of PHP $\left(1 \times 10^{-3} \mathrm{M}\right)$ and $2 \mathrm{~mL}$ of diazotized sulfacetamide sodium $\left(1 \times 10^{-3} \mathrm{M}\right)\left(\mathrm{A}_{\mathrm{S}}\right)$ with that of a solution containing a 5 -fold excess of diazotized sulfacetamide sodium $\left(A_{m}\right)$ and according to analytical procedure. The average stability constant was $(\mathrm{K})=4.399 \times 10^{7} \mathrm{~L}^{2} \mathrm{~mol}^{-2}$ where $\left(\mathrm{K}=[1-\alpha] / 4 \alpha^{3} \mathrm{C}^{2}\right.$; $\left.\alpha=\left[A_{m}-A_{s}\right] / A_{m}\right]$ [27]. This indicates a stable reaction product. The Gibbs free energy $(\Delta G)$ of this reaction was calculated adopting the following equation: $\Delta \mathrm{G}=-2.303 \mathrm{RT} \log \mathrm{K}$ where, $\mathrm{R}$ is the universal gas constant $\left(8.314 \mathrm{~J} \mathrm{~mole}^{-1} \mathrm{deg}^{-1}\right), \mathrm{T}$ is the absolute temperature $\left(273+25^{\circ} \mathrm{C}\right)$, and $\mathrm{K}$ is the stability constant of the reaction. The value of

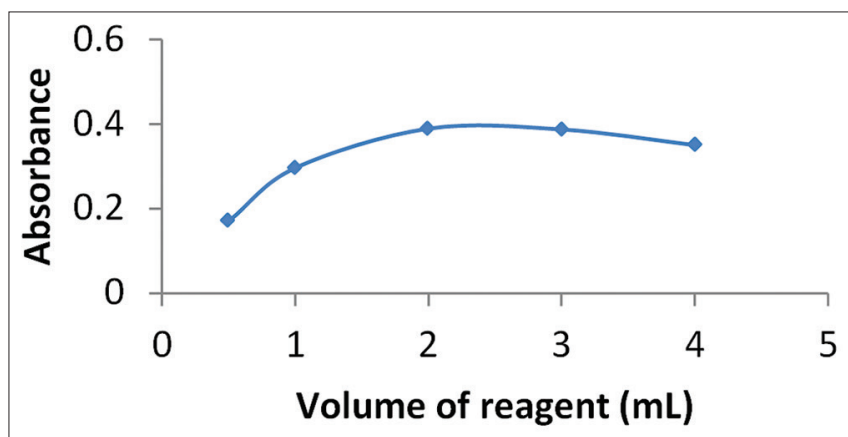

Fig. 3: Effect of the volume of sulfacetamide sodium $(0.1 \%)$ for the determination of phenylephrine hydrochloride $(20 \mu \mathrm{g} / \mathrm{mL})$

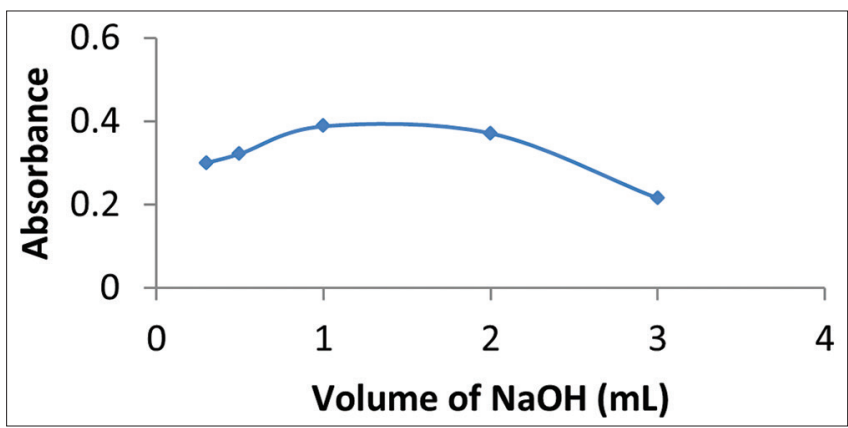

Fig. 4: Effect of the volume of $\mathrm{NaOH}(2 \mathrm{M})$ for the determination of phenylephrine hydrochloride $(20 \mu \mathrm{g} / \mathrm{mL})$ 


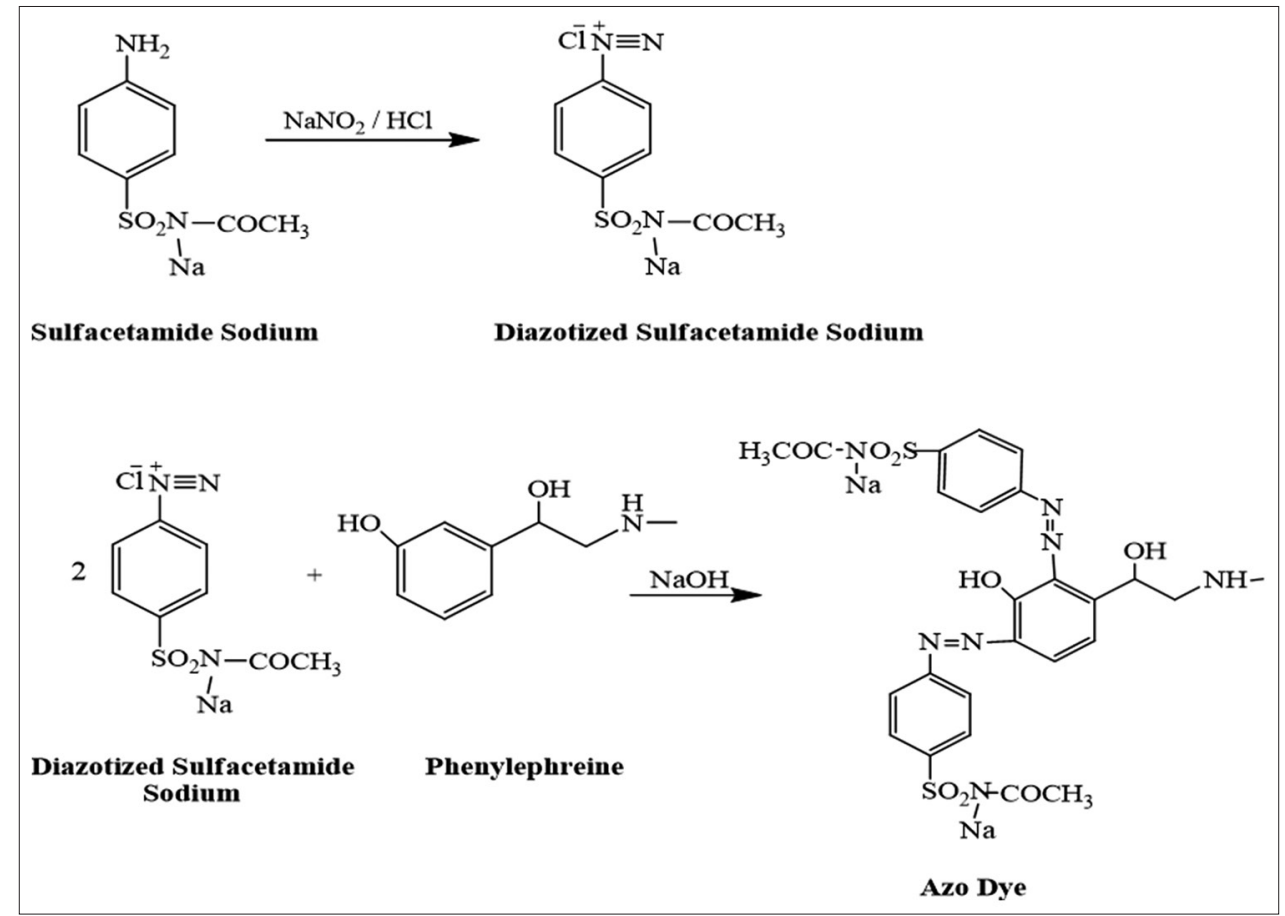

Scheme 1: Proposed mechanism of the reaction between phenylephrine hydrochloride and diazotized sulfacetamide sodium

Table 1: Determination of $20 \mu \mathrm{g} / \mathrm{mL}$ of PHP in the presence of excipients

\begin{tabular}{llll}
\hline Excipient $200 \mu \mathrm{g} / \mathrm{ml}$ & Conc. of phenylephrine, $\mathbf{2 0} \boldsymbol{\mu g} / \mathbf{m L}$ & $\mathbf{E}_{\text {rel. }}{ }^{*}(\mathbf{\%})$ & Rec.* $(\%)$ \\
\cline { 2 - 3 } & (Found*) & & 99.585 \\
\hline Lactose & 19.917 & -0.415 & 100.140 \\
Starch & 20.028 & 0.140 & 99.725 \\
Talc & 19.945 & -0.275 & 100.060 \\
Sodium chloride & 20.012 & 0.060 & 99.725 \\
Magnesium stearate & 19.945 & -0.275 & 100.275 \\
Polyvinylpyrrolidone & 19.986 & 0.275 & \\
\hline
\end{tabular}

${ }^{*}$ Average of four determinations, $\mathrm{E}_{\text {rel }}$ : Relative error, Rec.: Recovery

Table 2: Analytical data obtained from the determination of PHP hydrochloride

\begin{tabular}{ll}
\hline Parameter & Value \\
\hline$\lambda_{\text {max }}(\mathrm{nm})$ & 425 \\
Beer's law limits $(\mu \mathrm{g} / \mathrm{mL})$ & $2-24$ \\
Regression equation & $\mathrm{Y}=0.0169 \mathrm{X}+0.0084$ \\
Sandell's sensitivity $(\mu \mathrm{g} / \mathrm{mL})$ & $5.917 \times 10^{-5}$ \\
Molar absorptivity $\left(\mathrm{L} \mathrm{mol}^{-1} \mathrm{~cm}^{-1}\right)$ & $3.442 \times 10^{3}$ \\
Correlation coefficient $\left(\mathrm{R}^{2}\right)$ & 0.9929 \\
LOD $(\mu \mathrm{g} / \mathrm{mL})$ & 0.278 \\
Stability $(\mathrm{min})$ & 180 \\
Molar ratio $(\mathrm{D}: \mathrm{R})$ & $1: 2$ \\
Color & Yellow \\
\hline
\end{tabular}

LOD: Limit of detection

Table 3: Accuracy and precision for the proposed method

\begin{tabular}{llllll}
\hline \multicolumn{2}{l}{$\begin{array}{l}\text { Amount of PHP } \\
\text { hydrochloride }(\boldsymbol{\mu g} / \mathbf{m L})\end{array}$} & Recovery \% & $\mathbf{E}_{\text {rel. }} \%$ & RSD \% \\
\cline { 1 - 2 } \multicolumn{2}{l}{ Present } & Found & & & \\
\hline 12.00 & 11.771 & 98.092 & -1.908 & 1.266 \\
16.00 & 15.953 & 99.706 & -0.294 & 0.373 \\
\hline
\end{tabular}

$\mathrm{E}_{\mathrm{nel}}$ : Relative error, RSD: Relative standard deviation
$\Delta \mathrm{G}$ was found to be $-43.612 \mathrm{~kJ} / \mathrm{mole}$. The negative value of $\Delta \mathrm{G}$ refers to the spontaneity of the reaction.

\section{Interferences}

The extent of interfering by some excipients which often accompanied pharmaceutical preparations was studied by measuring the absorbance of solutions containing $20 \mu \mathrm{g} / \mathrm{mL}$ of PHP and excess amounts (10-fold excess) of each excipient, none of these substances interfered seriously (Table 1).

\section{Analytical characteristics of spectrophotometric method}

Calibration graph (Fig. 6) was obtained after optimized all the reaction conditions mentioned previously and a series of standard solutions were analyzed in triplicates to test the linearity. The molar absorptivity $(\varepsilon)$, the Sandell's sensitivity (S), the intercept (b), and the slope (a) were determined and are included in Table 2. The limit of detection was determined by taking the ratio of the standard deviation (SD) of the blank with respect to water and the slope of the calibration curve multiplied by the factor three [28].

The accuracy and precision of the proposed method were tested by analyzing five replicate of phenylephrine by proposed spectrophotometric method for two different concentrations of phenylephrine. The values of relative SD relative standard deviation $\%$ and relative error $\%$ are summarized in Table 3 . These values indicated the high accuracy and precision of the proposed method. 


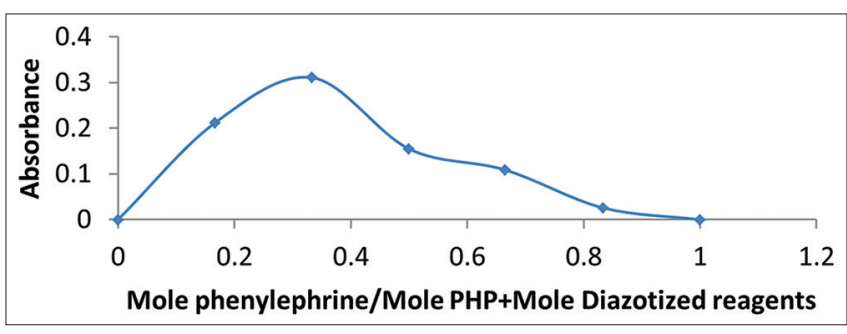

Fig. 5: Continuous variation plot

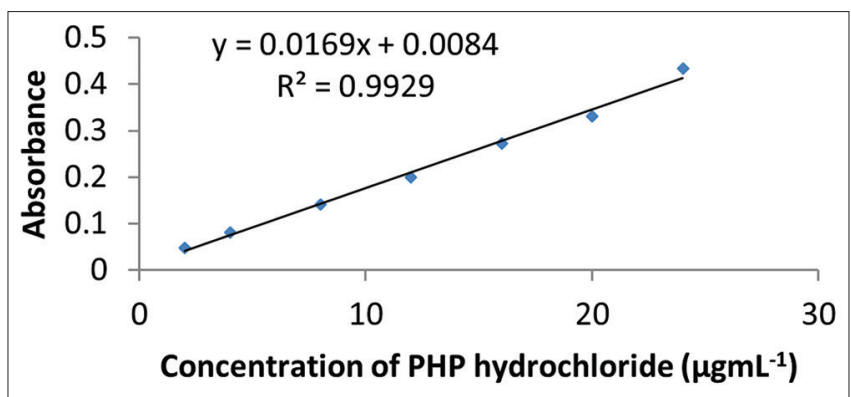

Fig. 6: Calibration graph of PHP hydrochloride

Table 4: Comparison of the proposed method with standard method for the determination of PHP in nasal drops

\begin{tabular}{lll}
\hline Pharmaceutical preparation & \multicolumn{2}{l}{ Recovery \% } \\
\cline { 2 - 3 } & $\begin{array}{l}\text { Proposed } \\
\text { method }\end{array}$ & $\begin{array}{l}\text { Standard } \\
\text { method }\end{array}$ \\
\hline Pure PHP & 98.899 & 100.000 \\
Nasophrine nasal drops $(0.25 \%)$ & 99.139 & 99.958 \\
Vibrocil nasal drops $(2.5 \mathrm{mg})$ & 98.454 & 98.923 \\
\hline
\end{tabular}

\section{Pharmaceutical application}

The proposed method was successfully applied to determine phenylephrine in nasal drops. The obtained results were compared statistically by a Student's t-test for accuracy and a variance ratio F-test for precision with the standard method [29] at the 95\% confidence level [30] as cited in Table 4. The results showed that the experimental $\mathrm{t}$-test and $\mathrm{F}$-test $(\mathrm{t}=1.962, \mathrm{~F}=3.079)$ were less than the theoretical value $\left(\mathrm{F}=19.00, \mathrm{t}=2.776\left(\mathrm{n}_{1}+\mathrm{n}_{2}-2=4\right)\right)$, indicating that there was no significant difference between the proposed method and standard method. Further, the proposed method is very economical when compared to chromatographic British pharmacopoeia methods [31].

In addition, a paired t-test [32] was conducted between the samples determined by proposed method with standard method. t-value (tab) for $\mathrm{n}-1$ degree of freedom $=4.303$ calculated $\mathrm{t}$-value $=1.322$ for $\mathrm{n}-1$ at $\alpha$ $0.05(95 \%)$, two tailed indicate that since $1.322<<4.303$; therefore, it can be regarded that there is no difference between the results.

\section{CONCLUSIONS}

This research offers a simple spectrophotometric method for the determination of PHP hydrochloride in nasal drops. This method has the advantage of simplicity, speed, accuracy, and the use of inexpensive equipment. In addition, the present method, as compared with other expensive techniques such as HPLC-MS, electro-sensors, and capillary electrophoresis, is economical and cheap and has an excellent accuracy and precision.

\section{ACKNOWLEDGMENT}

The author is grateful to the Chemistry Department, College of Science, Baghdad University, for providing facilities.

\section{AUTHOR CONTRIBUTION}

Wasan A. Al-Uzri: The idea of research, preparation of reagents and solutions with execution of experiments, data interpretation, and manuscript writing.

\section{CONFLICTS OF INTEREST}

There are no conflicts of interest.

\section{REFERENCES}

1. Council of Europe. European Pharmacopoeia. $3^{\text {rd }}$ ed. Strasbourg: Council of Europe; 1996

2. The Stationery Office. British Pharmacopoeia on CD-ROM. $3^{\text {rd }}$ ed. London: System Simulation Ltd., The Stationery Office; 2000.

3. Goodman A, Rall T, Nier A, Taylor P. The Pharmacology Bases of Therepeutics. New York: McGraw-Hill; 1996.

4. H.M. Stationary Office. British Pharmacopaeia. London: H.M. Stationary Office; 2001.

5. Goth A. Medical Pharmacology Principle and Concepts. $10^{\text {th }}$ ed. St. Louis, MO: The Mosby C.V. Company; 1981.

6. Hasan SH, Othman NS, Surchi KM. Determination of phenylephrine$\mathrm{HCl}$ using conductometric titration method. Curr Anal Chem 2016;12:330-4.

7. Yagmur S, Ture M, Saglikoglu G, Sadikoglu M, Yilmaz S. The quantitative detection of phenylephrine in pharmaceutical preparations and spiked human urine by voltammetry. Russ $\mathrm{J}$ Electrochem 2018;54:741-6.

8. Huang F, Jin G, Liu Y, Kong J. Sensitive determination of phenylephrine and chlorprothixene at poly(4-aminobenzene sulfonic acid) modified glassy carbon electrode. Talanta 2008;74:1435-41.

9. Pourghobadi Z, Niazi A. Voltametric study and determination of phenylephrine hydrochloride at INP-Nafion-modified CPE sensor employing differential pulse voltammetry. J Pure Appl Chem 2014;30:219-27.

10. Hegazy MA, Al-Ghobashy MA, Eltanany BM, Khattab FI. Purity indicating TLC method for quantitative determination of phenylephrine and dimethin dine maleate in presence of dimethin dine maleate impurity: 2-ethyl pyridine in nasal gel. J Pharm Res 2016;1:1-6.

11. Bandelwar R, Nikam A, Sawant S. Analytical method development and validation of phenylephrine hydrochloride, chlorpheniramine maleate, paracetamol and caffeine in bulk drug and tablet dosage form by RP-HPLC. Indo Am J Pharm Res 2013;3:4330-8.

12. Dewani AP, Dabhade SM, Bakal RL, Gadewar CK, Chandewar AV, Patra AV. Development and validation of a novel RP-HPLC method for simultaneous determination of paracetamol, phenylephrine hydrochloride, caffeine, cetirizine and nimesulide in tablet formulation. Arab J Chem 2015;8:591-8.

13. Michal D, Petr G. Fast HPLC method using ion-pair and hydrophilic interaction liquid chromatography for determination of phenylephrine in pharmaceutical formulations. J AOAC Int 2010;93:1436-42.

14. Patel DM, Chaudhary AB, Patel BD. Development and validation of RP-HPLC method for simultanous estimation of beclomethasone dipropionate, phenylephrine hydrochloride and lignocaine hydrochloride in cream. World J Pharm Pharm Sci 2018;7:829-41.

15. Al-Abachi MQ, Abed SS. Flow injection-spectrophotometric determination of phenylephrine hydrochloride and amoxicillin trihydrate in pharmaceutical preparations. J Al-Nahrain Univ 2013;16:42-52.

16. Rocha JR, Galhardo CX, Natividade MA, Masini JC. Spectrophotometric determination of phenylephrine hydrochloride in pharmaceuticals by flow injection analysis exploiting the reaction with potassium ferricyanide and 4-aminoantipyrine. J AOAC Int 2002;85:875-8

17. Mestre YF, Zamora YF, Lahuerta L, Martínez CJ. Determination of phenylephrine hydrochloride by flow injection analysis with chemiluminescence detection. J AOAC Int 2001;84:13-8.

18. Salem YA, Hammouda ME, Abu El-Enin MA, El-Ashry SM. Application of derivative emission fluorescence spectroscopy for determination of ibuprofen and phenylephrine simultaneously in tablets and biological fluids. Spectrochim Acta A Mol Biomol Spectrosc 2019;210:387-97.

19. Fawzy MA, Ekram AE, Essam MH, Mohamed FK, Hamdy MA. Spectrophotometric analysis of two eye preparations, vial and drops, containing ketorolac tromethamine and phenylephrine hydrochloride binary mixture and their ternary mixture with chlorphenirmaine maleate. Bull Fac Pharm Cairo Univ 2018;56:91-100.

20. Al-Sabha TN. Spectrophotometric assay of phenylephrine hydrochloride 
using 4-aminoantipyrine and copper (II). Pak J Anal Environ Chem 2010;11:1-7.

21. Ahmed IS, Amin AS. Spectrophotometric microdetermination of phenylephrine hydrochloride in pure and in pharmaceutical formulations using haematoxylin. J Mol Liq 2007;130:84-7.

22. Al-Abachi MQ, Abed SS. Spectrophotometric determination of phenylephrine hydrochloride and salbutamol sulphate drugs in pharmaceutical preparations using diazotized metoclopramide hydrochloride. Baghdad Sci J 2015;12:167-77.

23. Savić I, Nikolić G, Banković V. Development and validation of spectrophotometric method for phenylephrine estimation in nasal drops formulations. J Chem Chem Eng 2008;27:149-56.

24. Othman NS, Fatah NT. Indirect spectrophotometric determination of phenylephrine hydrochloride in pharmaceutical preparations. Tikrit J Pure Sci 2011;16:74-82.

25. Habibur R. Utilization of eosin dye as an ion pairing agent for determination of pharmaceuticals: A brief review. Int J Pharm Pharm
Sci 2017;9:1.

26. Sharma DK, Jasvir S, Pushap R. Spectrophotometric determination of propranolo hydrochloride and metopranol tartrate in pharmaceutical dosage forms, spiked water and biological fluids. Int J Pharm Pharm Sci 2018;10:107.

27. Al-Abachi MQ, Al-Ghabsha TS. Fundamentals of Analytical Chemistry. Mosul: Press of Mosul University; 1983.

28. Sanders DH, Murph AF. Statistics. New York: McGraw-Hill; 1976.

29. System Simulation Ltd., the Stationary Office. British Pharmacopeia on CD-ROM. London: System Simulation Ltd., the Stationary Office; 2005.

30. De-Levie R. Principles of Quantitative Chemical Analysis. Singapore: The McGraw-Hill Companies, Inc.; 1997. p. 221.

31. H.M. Stationary Office. British Pharmacopaeia. London: H.M. Stationary Office; 2007.

32. Miller JN, Miller JC. Statistics and Chemometrics for Analytical Chemistry. 4th ed. London: Pearson Education Limited; 2000. 